\title{
Effects of phosphorus-containing additives on soy and cottonseed protein as wood adhesives
}

\author{
H. N. Cheng ${ }^{*}$, Catrina Ford, Michael K. Dowd, Zhongqi He \\ Southern Regional Research Center, USDA Agricultural Research Service, 1100 Robert E. Lee \\ Blvd., New Orleans, LA 70124, USA
}

\begin{abstract}
Soy and cottonseed proteins appear promising as sustainable and environment-friendly wood adhesives. Because of their higher cost relative to formaldehyde-based adhesives, improvement in the adhesive performance of proteins is needed. In this work, we evaluated the adhesive properties of soy and cottonseed protein formulations that included phosphorus-containing acids and esters. For cottonseed protein isolate, most of these additives improved dry adhesive strength, with methylphosphonic acid, phosphorous acid, and phosphoric acid increasing the dry strength by 47,44 , and $42 \%$, respectively, at their optimal concentrations. For soy protein isolate, these additives did not show significant benefits. The phosphorus-containing additives also improved the hot water resistance of the cottonseed protein formulations but showed either no effect or a negative effect for the of soy protein formulations. Thus, the combination of cottonseed protein with phosphorus additives appears to be attractive as wood adhesives.
\end{abstract}

Keywords: Adhesive strength, cottonseed protein; phosphorus compounds; soy protein; water resistance; wood adhesive 


\section{Introduction}

Cotton is one of the world's most important industrial crops. The United States is ranked third in cotton production, behind China and India [1]. Most of the cotton land area in the U.S. is in the Southern and Western states, e.g., Texas, Georgia, Mississippi, Alabama, North Carolina and California [2]. Economically the most important part of the cotton plant is the fiber, which is used mostly in textiles. However, the plant also yields various products from the seed [3]. For example, cottonseed linters are converted to cellulosic derivatives and used to form coatings and films; cottonseed oil is an important edible oil; and cottonseed meal contains high levels of protein, which is used primarily as animal feed [3,4]. Through suitable processing, cottonseed protein isolate can be obtained from cottonseed meal [5-8].

In recent years there has been interest in using soy protein as a sustainable and ecofriendly replacement for formaldehyde-containing resins in wood adhesives [9-19]. This is driven in part by the desire to decrease dependence on petroleum resources and in part to decrease exposure to formaldehyde, which is a known carcinogen. However, soy protein is more costly than formaldehyde-based resins, and its adhesive properties are generally inferior [20,21]. Further improvement in the performance of protein adhesives is desirable, which will help to mitigate the benefit/cost disadvantage of protein.

It has been reported that cottonseed protein isolate performs better than soy protein isolate in both dry adhesive strength and hot water resistance [22] and that cottonseed protein isolate can be added to soy protein isolate to improve the latter's adhesive performance [23]. Water- or buffer-washed cottonseed meals have also been shown to be cheaper adhesive alternatives to cottonseed protein isolate [24-28]. A variety of modifiers, such as sodium dodecyl sulfonate, urea, and guanidine hydrochloride, have been reported to improve the adhesive properties of soy $[10,11,22,29,30]$ and cottonseed proteins [22]. Other modifiers previously studied with soy proteins include plasticizers [31], cationic detergents [32], ethylene glycol and its polymers [33], cationic polyacrylamide [34], cationic poly(aminoamide) [14,17,18], clay [35], calcium carbonate [36], and acid/base/salt combinations [37]. Recently several amino acids and carboxylic acids were shown to improve adhesive strength to cottonseed proteins but not to soy proteins [38].

In view of the beneficial effects of carboxylic acids on the adhesion of cottonseed protein [38], we decided to examine the effects of phosphorus-containing acids and esters in protein 
adhesive formulations. Many of these compounds are cheap and readily available. We hypothesized that at least some of these compounds would have positive effects on the proteinbased adhesive performance.

\section{Materials and methods}

\subsection{Materials}

Maple wood veneer (0.6 mm thick) was purchased from Oakwood Veneer Company (Troy, MI, USA). For dry adhesive strength testing, each veneer was cut into strips $12.7 \mathrm{~mm}$ wide by $88.9 \mathrm{~mm}$ long, with the wood grain parallel to the long side. For the hot water resistance testing, the same maple veneers were cut into strips $25.4 \mathrm{~mm}$ wide and $88.9 \mathrm{~mm}$ long, again aligning the wood grain to the long side. In addition, a thicker maple wood veneer $(1.59 \mathrm{~mm}$ thick) was purchased from Certainly Wood, Inc. (East Aurora, NY, USA), cut to the same size and was also used for the hot water test.

Cottonseed protein isolate was prepared from defatted glandless cottonseed meal by the one-step alkaline extraction and acid precipitation procedure reported by Berardi et al [4] and Martinez et al [5]. The nitrogen content of this isolate was 16.0\%. Soy protein isolate (tradename Pro-Fam 781) was provided by Archer Daniels Midland Company (Decatur, IL, USA); its nitrogen content was $14.2 \%$. When $3 \mathrm{~g}$ of the protein was dispersed in $25 \mathrm{~g}$ of water, the slurry $\mathrm{pH}$ was 4.8 for cottonseed protein and 6.75 for soy protein. For convenience, we have used the terms "cottonseed protein" and "soy protein" to refer to the protein isolates for the rest of this article.

Phosphoric acid, phosphorous acid, methyl phosphonic acid, octadecyl phosphonic acid, bis(2-ethylhexyl) phosphate, diethyl phosphite, tetrapotassium pyrophosphate, polyphosphoric acid, and phytic acid were purchased from Sigma Aldrich (St. Louis, Missouri, USA). Metaphosphoric acid was purchased from J.T. Baker Chemical Company (Phillipsburg, New Jersey, USA). Sodium monododecyl phosphate was purchased from TCI (Portland, Oregon, USA) and sodium trimetaphosphate was provided by Innophos (Cranbury, New Jersey, USA).

\subsection{Preparation of protein adhesives and bonded wood specimens}

Adhesive formulations were adapted from literature reports [10,11,13,22]. Protein slurries were prepared by stirring $3 \mathrm{~g}$ protein in $25 \mathrm{~mL}$ distilled water for $2 \mathrm{hr}$ at room 
temperature. For formulations containing additives, the protein $(3 \mathrm{~g})$ and additive (between 27 and $446 \mathrm{mM}$ final concentration) was suspended in $25 \mathrm{~g}$ distilled water and stirred for $2 \mathrm{hr}$ at room temperature. The $\mathrm{pH}$ for each additive formulation was adjusted with hydrochloric acid or sodium hydroxide to the same value as that of the protein formulation without the additive.

For the dry adhesive strength testing, the 0.6-mm thick maple veneers were used. Each adhesive preparation was applied with a brush to one side and one end of two veneer strips covering an area of $12.7 \mathrm{~mm} \times 25.4 \mathrm{~mm}$. The wet adhesive was allowed to air-dry for $10 \mathrm{~min}$ or until tacky, then a second layer was applied on top of the first layer and air-dried again for the same time period. The tacky adhesive-coated areas of a pair of wood veneer strips were stacked together to form a bonded area of $12.7 \mathrm{~mm}$ x $25.4 \mathrm{~mm}$. Ten pairs of stacked strips (corresponding to the testing of each adhesive formulation) were then hot-pressed for $20 \mathrm{~min}$ at $80{ }^{\circ} \mathrm{C}$ and 2.76 MPa in a Model 3856 Carver press (Carver Inc., Wabash, IN, USA). The lower temperature of $80^{\circ} \mathrm{C}$ was used because at $100^{\circ} \mathrm{C}$ or higher temperatures the wood strips showed some tendency to break due to the strong adhesive strength of cottonseed protein [22].

\subsection{Adhesive strength measurements}

Adhesive strength was measured in the shear mode with the bonded strips with a Zwick tensile tester (Zwick GmbH \& Co., Ulm, Germany). The instrument was fitted with $32 \mathrm{~mm}$ x 40

$\mathrm{mm}$ fish-scale gridded wedge grips and operated with a crosshead speed of $1 \mathrm{~mm} \mathrm{~min}^{-1}$. Bond strength was reported as the maximum tensile strength at break (MPa) and the elongation-atbreak (\%). Ten bonded wood strips were tested for each treatment, and the results reported as mean \pm standard deviation. Analysis of variance was used to compare differences in adhesive performance (SAS Institute, Cary, NC, USA).

\subsection{Hot water resistance test}

The procedure was similar to that used before [22,38] as adapted from earlier publications [10,15,16] and ASTM D1151-00 [39]. Both the maple veneers with $0.6 \mathrm{~mm}$ thickness and $1.58 \mathrm{~mm}$ thickness were used. Each adhesive preparation was again applied twice to the $25.4 \mathrm{~mm}$ end of the wood side of each veneer strip. Pairs of strips were overlapped and hot-pressed for $10 \mathrm{~min}$ at $100{ }^{\circ} \mathrm{C}$ and $1.38 \mathrm{MPa}$. After cooling, the bonded wood specimens were immersed in a water bath at $63 \pm 2{ }^{\circ} \mathrm{C}$ for $4 \mathrm{~h}$, and dried at room temperature for $24 \mathrm{~h}$. The 
immersion-drying cycle was then repeated, and the dried bonded specimens were tested on the Zwick tensile tester for maximum tensile strength and elongation-at-break. Ten bonded composites were evaluated for each adhesive preparation, and the result reported as mean \pm standard deviation. A higher value of tensile strength or elongation-at-break then denotes a greater degree of resistance to the hot water treatment.

\subsection{FT-IR}

Fourier-transform infrared (FT-IR) spectroscopy was conducted on solid samples using a Bruker Vertex 70 spectrometer (Billerica, MA, USA) coupled with the Opus software. Each spectrum was scanned in the frequency range of $650-4000 \mathrm{~cm}^{-1}$. Typically $1-64$ scans were taken at a spectral resolution of $8 \mathrm{~cm}^{-1}$.

\section{Results}

\subsection{Categorization of additives used}

A total of twelve phosphorus-containing compounds were studied, separated into three categories: acids containing a single phosphorus atom (Group 1), esters of phosphoruscontaining acids (Group 2), and acids containing multiple phosphorus atoms (Group 3). These represent some of the more commonly available phosphorus-containing acids and esters. For convenience, a sample code was assigned to each of the additives (Table 1).

\subsection{Dry adhesive strength testing}

The tensile strengths of the cottonseed protein and soy protein in the presence of different phosphorus-containing additives are summarized in Table 2. For convenience, we first compare the values for the proteins in the presence of a $27 \mathrm{mM}$ concentration of each additive (Table 2, column 3). The combinations with the highest tensile strength were cottonseed protein with phosphoric acid (1A), phosphorous acid (1B), methylphosphonic acid (1D), octadecyl phosphonic acid (1E), sodium trimetaphosphate (3A), tetrapotassium pyrophosphate (3B), and sodium polyphosphate (3C). The improvement in dry strength for these additives over the cottonseed protein control ranged from 22 to $34 \%$. With soy protein, most of the additives gave either the same or reduced tensile strength as the soy protein control. 
Since adhesion will depend on additive concentration, a more detailed dosage-dependent study was also carried out. Octadecyl phosphonate was expensive and was tested only at a 27 $\mathrm{mM}$ concentration. The adhesive performance of phytic acid was similar to other acids with multiple phosphorus atoms and was studied only at concentrations of 27 and $89 \mathrm{mM}$. The other 10 additives were tested at four concentrations with both cottonseed protein and soy protein, i.e., $27,54,89$, and $446 \mathrm{mM}$. A dependence of the tensile strength on the dosage level was found for each additive (Table 2, columns 3-6). It seemed that for the mono-phosphorus acids (Group 1) the optimal level was generally around $54 \mathrm{mM}$, but for the esters and the multi-phosphorus acids (Groups 2 and 3) the optimal level was about $27 \mathrm{mM}$. The maximum improvement (at the optimal level of each additive) is given in the last column of Table 2. The greatest improvements were observed for the Group 1 phosphates, i.e., methyl phosphonic acid (1D), phosphorous acid (1B), and phosphoric acid (1A), with, respectively, 47, 44, and 42\% increase in adhesive strength. Although the performance of the other phosphorus containing compounds with cottonseed protein was less, it was still significant, with tensile strength improvements between 11 and $32 \%$.

In contrast, soy protein showed much less improvement with the same additives (Table 2). Only phosphoric acid (1A), phosphorous acid (1B), sodium trimetaphosphate (3A) and tetrapotassium pyrophosphate (3B) exhibited improvements, which ranged from 7 to $11 \%$ over the soy protein control, and it was unclear if these improvements were statistically relevant. Three additives (octadecyl phosphonic acid (1E), sodium monododecyl phosphate (2B), and polyphosphoric acid (3C)) showed reduced strength relative to the soy protein control.

The results for elongation-at-break (Table 3) basically confirmed the data on tensile strength. Thus, the inclusion of phosphorus-containing additives to cottonseed protein formulations gave significantly greater elongation values (ranging between 14 and $44 \%$ ) over the elongation produced for the control cottonseed protein formulation. The best additives were again methyl phosphonic acid (1D), phosphoric acid (1A), and phosphorous acid (1B), with improvements of 44,38 , and $37 \%$, respectively. With soy protein, the use of these additives did not improve elongation, and in some cases resulted in reduced elongation.

In earlier publications [23,27], the data on the adhesive strength and elongation-at-break of wood veneers glued with protein adhesives were reported, and the two sets measurements were found to be highly correlated due to these plant protein-based adhesives behaving like 
thermoset resins [40]. In this work, the two values were again highly correlated. Additionally, both cottonseed and soy proteins showed the same correlation (Figure 1). Hence, elongation-atbreak can be used as an indication of adhesive bond strength for these types of samples under our testing conditions.

\subsection{Hot water resistance}

Although the wood application being studied is primarily for indoor use, it is useful to test the wood for water resistance. Indeed water resistance is an indicator of adhesive durability that is important for all wood products. For the hot water test, we studied cottonseed protein with the eight phosphorus compounds that produced the strongest dry joints. Soy proteins were studied together with the three compounds that produced the strongest joints with the soy proteins. Each additive was tested at its optimal concentration based on the dry strength results. Additionally, two different thicknesses of veneer were studied (Table 4). The first data set was based on the 0.6-mm thick maple veneer (column 3). For cottonseed protein with the additives, all the tensile strength values were statistically the same, and inclusion of each additive did not negatively affect the hot water resistance of the adhesives. With these cottonseed-glued veneers, however, significant numbers of wood breaks occurred during the tensile testing, which was due to the adhesive being stronger than the wood. Hence, these values give only a lower limit of strength. In contrast, for soy protein adhesives only the $27 \mathrm{mM}$ phosphoric acid additive did not affect the hot water resistance. The use of sodium trimetaphosphate or tetrapotassium pyrophosphate (both at $27 \mathrm{mM}$ ) decreased the hot water resistance for the soy protein (Table 4).

For better evaluation of the hot water resistance for the formulations, the same test was repeated with 1.59-mm maple veneer strips (column 5, Table 4). The thicker wood seemed to give somewhat larger standard deviations, but these veneers facilitated better differentiation among the eight phosphorus-containing additives used with the cottonseed protein samples. For these cottonseed glued samples, the hot water-treated tensile strength was improved by 10 to $46 \%$ (column 6, Table 4). The best tensile strength results were obtained for metaphosphoric acid (46\% over cottonseed protein control), phosphoric acid (40\%), phosphorous acid (38\%), and methyl phosphonic acid (37\%). All of these thicker wood strips glued with the soy protein formulations (including the soy protein control) failed during the hot water soak so that no adhesive performance data were possible. 


\subsection{FT-IR analysis}

FT-IR was used for characterization of the interactions between cottonseed protein and selected phosphorus-containing acids. Four samples were made, viz., 1) 10.7\% CSP only, 2) 10.7\% CSP and $100 \mathrm{mM}$ phosphoric acid, 3) 10.7\% CSP and $100 \mathrm{mM}$ phosphorous acid, and 4) CSP and $100 \mathrm{mM}$ methyl phosphonate. All samples were adjusted to $\mathrm{pH} 4.8$, water was removed, and the samples were placed in a hot press at $100^{\circ} \mathrm{C}$ for 20 minutes at $>1 \mathrm{MPa}$ pressure. The samples were then cooled and FTIR spectra taken (Figure 2). The IR spectrum of the cottonseed protein by itself (Figure 2a) is typical for a protein [41-43], with strong amide I and II bands at ca. 1650 and $1460 \mathrm{~cm}^{-1}$, respectively, and somewhat weaker amide III bands at around $1260 \mathrm{~cm}^{-1}$. Amide A and B bands (mainly N-H stretching) occur at ca. 3300 and 3080 $\mathrm{cm}^{-1}$, respectively. The peaks near $2900 \mathrm{~cm}^{-1}$ are $\mathrm{C}-\mathrm{H}$ stretching bands. The peak at $1455 \mathrm{~cm}^{-1}$ is

due to $\mathrm{CH}_{2}$ bending and the peak at $1395 \mathrm{~cm}^{-1}$ due to side chain $\mathrm{COO}^{-}$symmetric stretching [4143].

The FTIR spectra of the cottonseed protein with the three phosphorus acids (Figures 2bd) appear similar in overall features. The peaks of particular interest can be seen in the 800 $1300 \mathrm{~cm}^{-1}$ region. For example, a difference spectrum, obtained by subtracting the spectrum of cottonseed protein from the spectrum of cottonseed protein/phosphoric acid, is shown in Figure 3 , together with the spectrum of phosphoric acid by itself. It is well known that the IR spectrum of phosphoric acid in the $800-1300 \mathrm{~cm}^{-1}$ region depends on $\mathrm{pH}$ and the interactions with other species present [44-46]. At $\mathrm{pH} 4.8$, phosphoric acid exhibits $\mathrm{C}_{2 \mathrm{v}}$ symmetry and gives four peaks in this region, at ca. 1100, 1020, 940 and $870 \mathrm{~cm}^{-1}$ as shown in Figure 3b. These peaks become more complex in the cottonseed protein-phosphoric acid mixture (Figure 3a), suggesting the formation of intermolecular complexes, reminiscent of the adsorption of phosphate on ferrihydrite [45] and iron oxide [46].

\section{Discussion}

The addition of most of the phosphorus-containing additives improved the adhesive strength of the cottonseed proteins. Phosphoric acid, phosphorus acid, and methyl phosphonic acid all showed greater than $40 \%$ improvement in dry tensile strength and about $40 \%$ improvement in hot water resistance relative to the cottonseed protein control. Similar improvements were not observed for soy protein. Since phosphoric and phosphorous acids are 
cheap and readily available, the use of these additives with cottonseed protein will likely reduce the cost of adhesive formulations, making these formulations more viable as commercial products.

All of the tested compounds are small molecules that carry either an anionic charge (for an acid) or a partially charged dipole (for an ester). The adhesive performance of a protein in a wood adhesive formulation likely depends both on the interfacial coupling between the protein with the wood surface and on the formation of crosslinked structures among the denatured protein molecules during the heat bonding process $[23,38]$. Cottonseed and soy proteins have roughly the same total amount of histidine and lysine (8-9\%), but cottonseed protein contains more arginine $(11-12 \%)$ than does soy protein $(7-8 \%)$. Because arginine contains a guanidinium group having a $\mathrm{pK}_{\mathrm{a}}$ of 12.5 , it carries a net cationic charge at $\mathrm{pH}$ values up to 12 . The high $\mathrm{pKa}$ value ensures that the arginine side chain is protonated even when the guanidinium moiety is buried in a hydrophobic micro-environment, such as that inside a protein [47]. The cationic arginine moiety can help provide effective coupling between the protein and the anionic wood surface. Moreover, the anionic charge or anionic dipole in the phosphorus-containing additive may interact with the cationic arginine to form anion-protein electrostatic interactions, which may contribute to more effective energy dissipation and thereby enhanced strength and water resistance of the cottonseed protein-additive adhesive. For example, arginine and lysine in a protein are known to interact with negatively charged groups in the protein's ligand or substrate, such as the phosphoryl functionality [48]. Indeed, the FT-IR spectra obtained in this work (Figures 2-3) provide evidence for similar interaction between cottonseed protein and phosphoric acid. Further investigation into the behavior of cottonseed protein in the presence of different promoters is ongoing.

The effectiveness of the phosphorus compounds trended as follows: mono-phosphorus acids > multi-phosphorus acids > phosphorus esters. It is not surprising that phosphorus esters show the least effect because their interaction with arginine is likely to be dipolar and weaker than can be formed with an anionic charge. As for multi-phosphorus acids, perhaps their molecular structures, with close proximity of the anionic charges, do not permit optimal anion/cation interactions. Moreover, at the current dosages perhaps their use exceeds the anionic capacity of the formulations. 
Cottonseed protein adhesives with the best phosphorus additives (phosphoric and phosphorous acids) appear to be 2 to 3 times stronger than do soy protein adhesives. Another potential benefit of wood adhesives generated with phosphorus-containing additives is that many of these compounds are used as flame retardants, including methyl phosphonic acid, phosphate esters, and phosphonic esters [49-52]. Thus, the use of cottonseed protein with a phosphoruscontaining promoter may not only provide adhesion but also reduce wood flammability.

\section{Conclusions}

In this work, a number of phosphorus-containing additives were studied as promoters for cottonseed and soy protein isolate-based wood adhesion. Most of these compounds were shown to improve the adhesive performance of the cottonseed protein but had only a minor or insignificant effect on the performance of the soy protein. For the best promoters, the dry adhesive strength of cottonseed protein increased by over $40 \%$ compared to the unmodified cottonseed protein, and hot water resistance also improved by about $40 \%$. The improvement seems to be related to the interactions between the anionic phosphorus-containing functional group and the cationic arginine residue in cottonseed protein. This work suggests that the combination of cottonseed protein and phosphorus-containing compounds may be a promising and environmentally friendly formulation that is useful in construction adhesive applications.

\section{Acknowledgements}

We thank Scott Pelitire for preparing the cottonseed protein isolate, Dorselyn Chapital for procuring the thicker maple wood veneer, and Dr. Chanel Fortier for help with the FT-IR data. Sodium trimetaphosphate was provided by Innophos and soy protein by Archer Daniels Midland Company. Mention of trade names or commercial products in this publication is solely for the purpose of providing specific information and does not imply recommendation or endorsement by the U.S. Department of Agriculture. USDA is an equal opportunity provider and employer.

\section{References}

[1] Meyer L, MacDonald S. Cotton and Wool Outlook. United States Department of Agriculture Economic Research Service. 14 July, 2016. Retrieved 1 August 2016. http://www.ers.usda.gov/media/2115617/cws-16g.pdf 
[2] Statista - the statistical portal. Retrieved 9 June 2016. http://www.statista.com/statistics/248776/top-10-us-states-for-cotton-production/

[3] Dowd MK. Seed. In Cotton, Fang DD, Percy RG (Eds.). Agronomy Monograph 57. American Society of Agronomy, Inc., Crop Science Society of America, Inc., and Soil Science Society of America, Inc., Madison, Wisconsin: 2015, pp. 745-781.

[4] Cotton counts. Retrieved 9 June 2016. https://www.cotton.org/pubs/cottoncounts/story/importance.cfm

[5] Berardi LC, Martinez WH, Fernandez CJ. Cottonseed protein isolates: two step extraction procedure. Food Tech 1969; 23:75-82.

[6] Martinez WH, Berardi LC, Goldblatt LA. Cottonseed protein products - composition and functionality. J Agric Food Chem 1970; 18: 961-968.

[7] Gerasimidis K, Fillou DT, Babatzimcpoulou M, Tassou K, Katsikas H. Preparation of an edible cottonseed protein concentrate and evaluation of its functional properties. Int $\mathbf{J}$ Food Sci Nutrition 2007; 58: 486-490.

[8] Zhang B, Cui Y, Yin G, Li X, Zhou X. Alkaline extraction method of cottonseed protein isolate. Modern Appl Sci 2009; 3: 77-82.

[9] Kalapathy U, Hettiarachchy NS, Myers D, Hanna MA. Modification of soy proteins and their adhesive properties on wood. J Am Oil Chem Soc 1995; 72: 507-510.

[10] Sun S, Bian K. Shear strength and water resistance of modified soy protein adhesives. J Am Oil Chem Soc 1999; 76: 977-980.

[11] Zhong Z, Sun XS, Fang X, Ratto JA. Adhesive strength of guanidine hydrochloridemodified protein for fiberboard application. Int J Adhes Adhes 2002; 22: 267-272.

[12] Kumar R, Choudhary V, Mishra S, Varma I, Mattiason B. Adhesives and plastics based on soy protein products. Ind Crop Prod 2002; 16: 155-172.

[13] Sun XS, Wang D, Zhong Z. Adhesion performance of modified soy protein adhesive. DOD report, 2002. http://dodreports.com/pdf/ada414303.pdf

[14] Li K., Peshkova S, Geng X. Investigation of soy protein-Kymene adhesive system for wood composites. J Am Oil Chem Soc 2004; 81:487-491.

[15] Li K, Geng X, Simonsen J, Karchesy J. Novel wood adhesives from condensed tannins and polyethylenimine. Int J Adh Adhes 2004; 24: 327-333. 
[16] Liu Y, Li K. Development and characterization of adhesives from soy protein for bonding wood. Int J Adhes Adhes 2007; 27: 59-67.

[17] Zhong Z, Sun XS, Wang D. Isoelectric pH of polyamide-epichlorohydrin modified soy protein improved water resistance and adhesion properties. J Appl Polym Sci 2007; 130: 2261-2270.

[18] Allen AJ, Marcinko JJ, Wagler TA, Sosnowick AJ. Investigations of the molecular interactions of soy-based adhesives. Forest Prod J 2010; 60(6): 534-540.

[19] Frihart CR, Birkeland MJ. Soy properties and soy wood adhesives. Am Chem Soc Symp Series 2014; 1178: 167-192. DOI: 10.1021/bk-2014-1178.ch008

[20] Pizzi A. Recent developments in eco-efficient bio-based adhesives for wood bonding: opportunities and issues. J Adhes Sci Technol 2006; 20(8): 829-846.

[21] Orr L. Wood adhesives - A market opportunity study. Omni Tech International, Ltd., Midland, Michigan; 2007. http://www.soynewuses.org/downloads/reports/final_WoodAdhesivesMarketOpportunity.pdf

[22] Cheng HN, Dowd MK, He Z. Investigation of modified cottonseed protein adhesives for wood composites. Ind Crop Prod 2013; 46: 399-403.

[23] Cheng HN, Ford C, Dowd MK, He Z. Soy and cottonseed protein blends as wood adhesives. Ind Crop Prod 2016; 85: 324-330.

[24] He Z, Chapital DC, Cheng HN. Comparison of the adhesive performance of soy meal, water washed meal fractions, and protein isolates. Modern Appl Sci 2016; 10: 112-120.

[25] He Z, Cao H, Cheng HN, Zou H, Hunt JF. Effects of vigorous blending on yield and quality of protein isolates extracted from cottonseed and soy flours. Modern Appl Sci 2013; 7(10): 79-88.

[26] He Z, Chapital DC, Cheng HN, Dowd MK. Comparison of adhesive properties of waterand phosphate buffer-washed cottonseed meals with cottonseed protein isolate on maple and poplar veneers. Int J Adhes Adhes 2014; 50: 102-106.

[27] He Z, Cheng HN, Chapital DC, Dowd MK. Sequential fractionation of cottonseed meal to improve its wood adhesive properties. J Am Oil Chem Soc 2014; 91: 151-158.

[28] He Z, Chapital DC, Cheng HN, Modesto O, Adhesive properties of water washed cottonseed meal on four types of wood. J Adhes Sci Technol 2016; 30(19): 2109-2119. 
[29] Huang W, Sun X. Adhesive properties of soy protein modified by urea and guanidine hydrochloride. J Am Oil Chem Soc 2000; 77:101-104.

[30] Huang W, Sun X. Adhesive properties of soy protein modified by sodium dodecyl sulfate and sodium dodecylbenzene sulfonate. J Am Oil Chem Soc 2000; 77:705-708.

[31] Mo X, Sun X. Plasticization of soy protein polymer by polyol-based plasticizers. J. Am. Oil Chem Soc 2002; 79: 197-202.

[32] Wang Y, Wang D, Sun XS. Thermal properties and adhesiveness of soy protein modified with cationic detergent. J. Am Oil Chem Soc 2005; 82: 357-363.

[33] Chen M, Chen Y, Zhou X, Lu B, He M, Sun S, Ling X. Improving water resistance of soyprotein wood adhesive by using hydrophilic additives. BioResources 2015; 10: 41-54.

[34] Xu H, Luo J, Gao Q, Zhang S, Li J. Improved water resistance of soybean meal-based adhesives with SDS and PAM. BioResources 2014; 9: 4667-4678.

[35] Zhang Y, Zhu W, Lu Y, Gao Z, Gu J. Water-resistant soybean adhesive for wood binder employing combinations of caustic degradation, nano-modification, and chemical crosslinking. BioResources 2013; 8: 1283-1291.

[36] Liu D, Chen H, Chang PR, Wu Q, Li K, Guan L. Biomimetic soy protein nanocomposites with calcium carbonate crystalline arrays for use as wood adhesive. Bioresource Technol 2010; 101: 6235-6241.

[37] Lin Q, Chen N, Bian L, Fan M. Development and mechanism characterization of high performance soy-based bio-adhesives. Int J Adhes Adhes 2012; 34: 11-16.

[38] Cheng HN, Ford C, Dowd MK, He Z. Use of additives to enhance the properties of cottonseed protein as wood adhesives. Intl J Adhes Adhes 2016; 68: 156-160.

[39] ASTM 2013. Standard practice for effect of moisture and temperature on adhesive bonds (D1151-00). American Society of Testing and Materials, Philadelphia, PA, pp. 73-75.

[40] Kinloch AJ, Young RJ. Fracture Bahaviour of Polymers. Springer, Dordrecht, The Netherlands: 1995. p. 287.

[41] Barth A, Infrared spectroscopy of proteins. Biochim Biophys Acta 2007; 1767: 1073-1101.

[42] Bozkurt O, Bayari SH, Severcan M, Krafft C, Popp J, Severcan F. Structural alterations in rat liver proteins due to streptozotocin-induced diabetes and the recovery effect of selenium: Fourier transform infrared microspectroscopy and neural network study. J Biomed Optics 2012; 17: 076023. 
[43] Jonker JL, Morrison L, Lynch EP, Grunwald I, von Byem J, Power AM. The chemistry of stalked barnacle adhesive (Lepas anatifera). Interface Focus 2015; 5: 20140062. DOI: 10.1098/rsfs.2014.0062.

[44] Chapman AC, Thirlwell LE. Spectra of phosphorus compounds - I. The infra-red spectra of orthophosphates. Spectrochim Acta 1964; 20: 937-947.

[45] Arai Y, Sparks DL. ATR-FTIR spectroscopic investigation on phosphate adsorption mechanisms at the ferrihydrite-water interface. J Colloid Interf Sci 2001; 241: 317-326.

[46] Persson P, Nilsson N, Sjoberg S. Structure and bonding of orthophosphate ions at the iron oxide-aqueous interface. J Colloid Interf Sci 1996; 177: 263-275.

[47] Fitch CA, Platzer G, Okon M, Garcia-Moreno B, McIntosh LP. Arginine: Its pKa value revisited. Protein Sci. 2015; 24(5): 752-761.

[48] Kessel A, Ben-Tal N. Introduction to Proteins: Structure, Function, and Motion. CRC Press, Boca Raton, USA: 2010. p. 92.

[49] Schartel B. Phosphorus-based flame retardancy mechanisms-Old hat or a starting point for future development? Materials 2010; 3: 4710-4745.

[50] Levchik SV, Weil ED. A review of recent progress in phosphorus-base flame retardants. J Fire Sci 2006; 24: 345-364.

[51] Granzo A. Flame retardation by phosphorus compounds. Accts Chem Res 1978; 11: 177183.

[52] Antonov A, Potapova E, Rudakova T, Reshetnikov I, Zubkova N, Tuganova M, Khalturinskij N. Microencapsulated fire retardants in polymers. In Fire Retardency of Polymers. Le Bras M, Camino G, Bourbigot S, Delobel R (Eds.). Royal Soc Chem, Cambridge, UK: 1998. p. 291. 
Table 1. Samples used, categorization, and sample codes

\begin{tabular}{ll}
\hline Sample code & Phosphorus-containing additive \\
\hline 0 & Protein only, no additive
\end{tabular}

Group 1. Protein together with acids containing single phosphorus atom
$1 \mathrm{~A}$
$1 \mathrm{~B}$
Phosphoric acid
Phosphorous acid
$1 \mathrm{C}$
Metaphosphoric acid
$1 \mathrm{D}$
Methylphosphonic acid
$1 \mathrm{E}$
Octadecylphosphonic acid

Group 2. Protein together with phosphorus acid esters

2A

$2 \mathrm{~B}$

$2 \mathrm{C}$
Bis(2-ethylhexyl) phosphate

Sodium monododecyl phosphate

Diethyl phosphite

Group 3. Protein together with acids with multiple phosphorus atoms

$3 \mathrm{~A}$

$3 \mathrm{~B}$

$3 \mathrm{C}$

$3 \mathrm{D}$
Sodium trimetaphosphate

Tetrapotassium pyrophosphate

Polyphosphoric acid, sodium salt

Phytic acid 
Table 2. Tensile strength for cottonseed protein (CSP) and soy protein (SP) with different concentrations (c) of the additives ${ }^{*}$

\begin{tabular}{|c|c|c|c|c|c|c|}
\hline \multirow[t]{2}{*}{ Protein } & \multirow[t]{2}{*}{ Additive (code) } & \multicolumn{4}{|c|}{ Tensile strength $(\mathrm{MPa})^{* *}$} & \multirow{2}{*}{$\begin{array}{l}\% \text { max } \\
\text { increase }\end{array}$} \\
\hline & & $\mathrm{c}=27 \mathrm{mM}$ & $\mathrm{c}=54 \mathrm{mM}$ & $\mathrm{c}=89 \mathrm{mM}$ & $c=446 \mathrm{mM}$ & \\
\hline \multirow[t]{13}{*}{ CSP } & none $(0)$ & $2.52 \pm 0.08^{\mathrm{e}}$ & $2.52 \pm 0.08^{\mathrm{d}}$ & $2.52 \pm 0.08^{\mathrm{e}, \mathrm{f}}$ & $2.52 \pm 0.08^{b}$ & 0 \\
\hline & Phosphoric acid (1A) & $3.20 \pm 0.30^{\mathrm{a}, \mathrm{b}}$ & $3.57 \pm 0.34^{\mathrm{a}}$ & $3.34 \pm 0.43^{\mathrm{a}, \mathrm{b}}$ & $2.97 \pm 0.34^{\mathrm{a}}$ & 42 \\
\hline & Phosphorous acid (1B) & $3.06 \pm 0.15^{\mathrm{a}, \mathrm{b}, \mathrm{c}}$ & $3.61 \pm 0.17^{\mathrm{a}}$ & $3.23 \pm 0.23^{\mathrm{a}, \mathrm{b}, \mathrm{c}}$ & $2.73 \pm 0.25^{\mathrm{a}, \mathrm{b}}$ & 44 \\
\hline & Metaphosphoric acid (1C) & $2.52 \pm 0.12^{\mathrm{e}}$ & $2.70 \pm 0.21^{\mathrm{c}, \mathrm{d}}$ & $3.06 \pm 0.28^{\mathrm{b}, \mathrm{c}, \mathrm{d}}$ & $1.90 \pm 0.22^{\mathrm{c}, \mathrm{d}}$ & 22 \\
\hline & $\begin{array}{l}\text { Methylphosphonic acid } \\
\text { (1D) }\end{array}$ & $3.34 \pm 0.17^{\mathrm{a}}$ & $3.70 \pm 0.32^{\mathrm{a}}$ & $3.43 \pm 0.34^{\mathrm{a}}$ & $2.57 \pm 0.23^{b}$ & 47 \\
\hline & $\begin{array}{l}\text { Octadecyl phosphonic acid } \\
\text { (1E) }\end{array}$ & $3.31 \pm 0.19^{\mathrm{a}}$ & & & & 32 \\
\hline & $\begin{array}{l}\text { Bis(2-ethylhexyl) } \\
\text { phosphate }(2 \mathrm{~A})\end{array}$ & $2.98 \pm 0.18^{\mathrm{b}, \mathrm{c}}$ & $2.55 \pm 0.17^{\mathrm{c}, \mathrm{d}}$ & $2.32 \pm 0.21^{\mathrm{f}}$ & failed & 19 \\
\hline & $\begin{array}{l}\text { Sodium monododecyl } \\
\text { phosphate (2B) }\end{array}$ & $2.79 \pm 0.15^{\mathrm{c}, \mathrm{d}, \mathrm{e}}$ & $2.68 \pm 0.30^{\mathrm{c}, \mathrm{d}}$ & $2.79 \pm 0.18^{\mathrm{d}, \mathrm{e}}$ & $1.19 \pm 0.07^{\mathrm{e}}$ & 11 \\
\hline & Diethyl phosphite (2C) & $2.65 \pm 0.21^{\mathrm{d}, \mathrm{e}}$ & $2.80 \pm 0.17^{\mathrm{b}, \mathrm{c}, \mathrm{d}}$ & $2.76 \pm 0.21^{\mathrm{d}, \mathrm{e}}$ & $2.87 \pm 0.17^{\mathrm{a}}$ & 14 \\
\hline & $\begin{array}{l}\text { Sodium trimetaphosphate } \\
\text { (3A) }\end{array}$ & $3.05 \pm 0.22^{\mathrm{a}, \mathrm{b}, \mathrm{c}}$ & $2.55 \pm 0.22^{\mathrm{c}, \mathrm{d}}$ & $2.36 \pm 0.41^{\mathrm{f}}$ & $1.70 \pm 0.21^{\mathrm{d}}$ & 22 \\
\hline & $\begin{array}{l}\text { Tetrapotassium } \\
\text { pyrophosphate (3B) }\end{array}$ & $3.03 \pm 0.22^{\mathrm{a}, \mathrm{b}, \mathrm{c}}$ & $2.90 \pm 0.29^{\mathrm{b}, \mathrm{c}}$ & $2.84 \pm 0.22^{\mathrm{d}, \mathrm{e}}$ & $2.08 \pm 0.23^{c}$ & 21 \\
\hline & Polyphosphoric acid (3C) & $3.05 \pm 0.29^{\mathrm{a}, \mathrm{b}, \mathrm{c}}$ & $3.09 \pm 0.30^{\mathrm{b}}$ & $2.91 \pm 0.28^{\mathrm{c}, \mathrm{d}}$ & $1.97 \pm 0.29^{\mathrm{c}, \mathrm{d}}$ & 23 \\
\hline & Phytic acid (3D) & $2.92 \pm 0.35^{\mathrm{b}, \mathrm{c}, \mathrm{d}}$ & & $2.30 \pm 0.12^{\mathrm{f}}$ & & 16 \\
\hline \multirow[t]{13}{*}{ SP } & none $(0)$ & $1.50 \pm 0.16^{\mathrm{a}, \mathrm{b}, \mathrm{c}}$ & $1.50 \pm 0.16^{\mathrm{a}, \mathrm{b}, \mathrm{c}}$ & $1.50 \pm 0.16^{\mathrm{b}, \mathrm{c}}$ & $1.50 \pm 0.16^{\mathrm{a}, \mathrm{b}}$ & 0 \\
\hline & Phosphoric acid (1A) & $1.44 \pm 0.15^{\mathrm{b}, \mathrm{c}}$ & $1.60 \pm 0.15^{\mathrm{a}}$ & $1.61 \pm 0.21^{\mathrm{b}}$ & $1.38 \pm 0.14^{\mathrm{b}, \mathrm{c}}$ & 7 \\
\hline & Phosphorous acid (1B) & $1.48 \pm 0.11^{\mathrm{a}, \mathrm{b}, \mathrm{c}}$ & $1.49 \pm 0.17^{\mathrm{a}, \mathrm{b}, \mathrm{c}}$ & $1.52 \pm 0.08^{\mathrm{b}, \mathrm{c}}$ & $1.60 \pm 0.14^{\mathrm{a}, \mathrm{b}}$ & 7 \\
\hline & Metaphosphoric acid (1C) & $1.39 \pm 0.07^{\mathrm{b}, \mathrm{c}}$ & $1.50 \pm 0.17^{\mathrm{a}, \mathrm{b}, \mathrm{c}}$ & $1.42 \pm 0.14^{\mathrm{b}, \mathrm{c}, \mathrm{d}}$ & $1.52 \pm 0.21^{\mathrm{a}, \mathrm{b}}$ & 1 \\
\hline & $\begin{array}{l}\text { Methylphosphonic acid } \\
\text { (1D) }\end{array}$ & $1.56 \pm 0.18^{\mathrm{a}, \mathrm{b}, \mathrm{c}}$ & $1.56 \pm 0.12^{\mathrm{a}, \mathrm{b}}$ & $1.45 \pm 0.17^{\mathrm{b}, \mathrm{c}, \mathrm{d}}$ & $1.39 \pm 0.25^{b, c}$ & 4 \\
\hline & $\begin{array}{l}\text { Octadecyl phosphonic acid } \\
\text { (1E) }\end{array}$ & $0.90 \pm 0.15^{\mathrm{d}}$ & & & & -40 \\
\hline & $\begin{array}{l}\text { Bis(2-ethylhexyl) } \\
\text { phosphate }(2 \mathrm{~A})\end{array}$ & $1.50 \pm 0.19^{\mathrm{a}, \mathrm{b}, \mathrm{c}}$ & $1.37 \pm 0.14^{\mathrm{b}, \mathrm{c}, \mathrm{d}}$ & $1.35 \pm 0.25^{\mathrm{d}}$ & $1.19 \pm 0.15^{\mathrm{c}}$ & 0 \\
\hline & $\begin{array}{l}\text { Sodium monododecyl } \\
\text { phosphate (2B) }\end{array}$ & $1.35 \pm 0.14^{\mathrm{c}}$ & $1.24 \pm 0.11^{\mathrm{d}}$ & $1.23 \pm 0.12^{\mathrm{d}}$ & $0.90 \pm 0.08^{\mathrm{d}}$ & -10 \\
\hline & Diethyl phosphite (2C) & $1.57 \pm 0.15^{\mathrm{a}, \mathrm{b}}$ & $1.49 \pm 0.11^{\mathrm{a}, \mathrm{b}, \mathrm{c}}$ & $1.56 \pm 0.10^{\mathrm{b}, \mathrm{c}}$ & $1.23 \pm 0.21^{\mathrm{c}}$ & 4 \\
\hline & $\begin{array}{l}\text { Sodium trimetaphosphate } \\
\text { (3A) }\end{array}$ & $1.43 \pm 0.14^{\mathrm{b}, \mathrm{c}}$ & $1.46 \pm 0.19^{\mathrm{a}, \mathrm{b}, \mathrm{c}}$ & $1.39 \pm 0.29^{\mathrm{b}, \mathrm{c}, \mathrm{d}}$ & $1.64 \pm 0.12^{\mathrm{a}}$ & 9 \\
\hline & $\begin{array}{l}\text { Tetrapotassium } \\
\text { pyrophosphate (3B) }\end{array}$ & $1.66 \pm 0.10^{\mathrm{a}}$ & $1.32 \pm 0.10^{\mathrm{c}, \mathrm{d}}$ & $1.59 \pm 0.21^{\mathrm{b}, \mathrm{c}}$ & $1.66 \pm 0.14^{\mathrm{a}}$ & 11 \\
\hline & Polyphosphoric acid (3C) & $1.39 \pm 0.12^{\mathrm{b}, \mathrm{c}}$ & $1.41 \pm 0.07^{\mathrm{a}, \mathrm{b}, \mathrm{c}, \mathrm{d}}$ & $1.34 \pm 0.18^{\mathrm{c}, \mathrm{d}}$ & $1.26 \pm 0.21^{\mathrm{c}}$ & -6 \\
\hline & Phytic acid (3D) & $1.52 \pm 0.17^{\mathrm{a}, \mathrm{b}, \mathrm{c}}$ & & $1.41 \pm 0.14^{\mathrm{b}, \mathrm{c}, \mathrm{d}}$ & & 1 \\
\hline
\end{tabular}

${ }^{*}$ Tests conducted on bonded maple wood strips $12.7 \mathrm{~mm}$ x $88.9 \mathrm{~mm}$ with a glued $12.7 \mathrm{~mm}$ x $25.4 \mathrm{~mm}$ overlap between the two strips. Each result is shown as mean \pm standard deviation.

${ }^{* *}$ Data for a set of protein/additive combinations at a specific additive concentration were subjected to analysis of variance; the same superscript letters in a semi-column indicate that the values are not significantly different at $\mathrm{p}=0.05$. 
Table 3. Elongation-at-break for cottonseed protein (CSP) and soy protein (SP) with different concentrations (c) of the additives ${ }^{*}$

\begin{tabular}{|c|c|c|c|c|c|c|}
\hline \multirow[t]{2}{*}{ Protein } & \multirow[t]{2}{*}{ Additive (code) } & \multicolumn{4}{|c|}{ Elongation-at-break (\%) } & \multirow{2}{*}{$\begin{array}{l}\% \max \\
\text { increase }\end{array}$} \\
\hline & & $\mathrm{c}=27 \mathrm{mM}$ & $\mathrm{c}=54 \mathrm{mM}$ & $\mathrm{c}=89 \mathrm{mM}$ & $\mathrm{c}=446 \mathrm{mM}$ & \\
\hline \multirow[t]{13}{*}{ CSP } & none $(0)$ & $1.78 \pm 0.09^{\mathrm{d}}$ & $1.78 \pm 0.09^{\mathrm{d}}$ & $1.78 \pm 0.09^{\mathrm{d}, \mathrm{e}, \mathrm{f}}$ & $1.78 \pm 0.09^{b}$ & 0 \\
\hline & Phosphoric acid (1A) & $2.21 \pm 0.17^{\mathrm{a}, \mathrm{b}}$ & $2.45 \pm 0.21^{\mathrm{a}}$ & $2.37 \pm 0.27^{\mathrm{a}, \mathrm{b}}$ & $2.15 \pm 0.19^{\mathrm{a}}$ & 38 \\
\hline & Phosphorous acid (1B) & $2.19 \pm 0.18^{\mathrm{a}, \mathrm{b}}$ & $2.43 \pm 0.12^{\mathrm{a}}$ & $2.29 \pm 0.17^{\mathrm{a}, \mathrm{b}}$ & $1.95 \pm 0.14^{\mathrm{b}}$ & 37 \\
\hline & Metaphosphoric acid (1C) & $1.81 \pm 0.08^{\mathrm{d}}$ & $1.95 \pm 0.13^{\mathrm{b}, \mathrm{c}, \mathrm{d}}$ & $2.18 \pm 0.20^{\mathrm{b}, \mathrm{c}}$ & $1.50 \pm 0.16^{\mathrm{c}}$ & 22 \\
\hline & $\begin{array}{l}\text { Methylphosphonic acid } \\
\text { (1D) }\end{array}$ & $2.39 \pm 0.14^{\mathrm{a}}$ & $2.57 \pm 0.24^{\mathrm{a}}$ & $2.44 \pm 0.22^{\mathrm{a}}$ & $1.88 \pm 0.15^{\mathrm{b}}$ & 44 \\
\hline & $\begin{array}{l}\text { Octadecyl phosphonic acid } \\
\text { (1E) }\end{array}$ & $2.38 \pm 0.16^{\mathrm{a}}$ & & & & 34 \\
\hline & $\begin{array}{l}\text { Bis(2-ethylhexyl) } \\
\text { phosphate }(2 \mathrm{~A})\end{array}$ & $2.03 \pm 0.19^{\mathrm{b}, \mathrm{c}}$ & $1.90 \pm 0.05^{\mathrm{c}, \mathrm{d}}$ & $1.77 \pm 0.14^{\mathrm{e}, \mathrm{f}}$ & failed & 14 \\
\hline & $\begin{array}{l}\text { Sodium monododecyl } \\
\text { phosphate (2B) }\end{array}$ & $2.06 \pm 0.12^{\mathrm{b}, \mathrm{c}}$ & $2.00 \pm 0.17^{\mathrm{b}, \mathrm{c}, \mathrm{d}}$ & $1.98 \pm 0.11^{\mathrm{c}, \mathrm{d}, \mathrm{e}}$ & $0.97 \pm 0.06^{\mathrm{e}}$ & 16 \\
\hline & Diethyl phosphite (2C) & $1.91 \pm 0.08^{\mathrm{c}, \mathrm{d}}$ & $2.03 \pm 0.14^{\mathrm{b}, \mathrm{c}}$ & $1.97 \pm 0.16^{\mathrm{c}, \mathrm{d}, \mathrm{e}}$ & $1.94 \pm 0.13^{b}$ & 14 \\
\hline & $\begin{array}{l}\text { Sodium trimetaphosphate } \\
\text { (3A) }\end{array}$ & $2.03 \pm 0.14^{\mathrm{b}, \mathrm{c}}$ & $1.87 \pm 0.14^{\mathrm{c}, \mathrm{d}}$ & $1.72 \pm 0.23^{\mathrm{f}}$ & $1.31 \pm 0.11^{\mathrm{d}}$ & 14 \\
\hline & $\begin{array}{l}\text { Tetrapotassium } \\
\text { pyrophosphate }(3 \mathrm{~B})\end{array}$ & $2.04 \pm 0.12^{\mathrm{b}, \mathrm{c}}$ & $2.05 \pm 0.19^{\mathrm{b}, \mathrm{c}}$ & $2.03 \pm 0.16^{\mathrm{c}}$ & $1.57 \pm 0.15^{\mathrm{c}}$ & 15 \\
\hline & Polyphosphoric acid (3C) & $2.21 \pm 0.23^{\mathrm{a}, \mathrm{b}}$ & $2.15 \pm 0.19^{b}$ & $2.01 \pm 0.17^{\mathrm{c}, \mathrm{d}}$ & $1.44 \pm 0.16^{\mathrm{c}, \mathrm{d}}$ & 24 \\
\hline & Phytic acid (3D) & $2.16 \pm 0.19^{b}$ & & $1.67 \pm 0.08^{\mathrm{f}}$ & & 21 \\
\hline \multirow[t]{13}{*}{ SP } & none $(0)$ & $1.20 \pm 0.12^{\mathrm{a}, \mathrm{b}}$ & $1.20 \pm 0.12^{\mathrm{a}, \mathrm{b}}$ & $1.20 \pm 0.12^{\mathrm{a}, \mathrm{b}}$ & $1.20 \pm 0.12^{\mathrm{a}, \mathrm{b}, \mathrm{c}, \mathrm{d}}$ & 0 \\
\hline & Phosphoric acid (1A) & $1.17 \pm 0.10^{\mathrm{a}, \mathrm{b}}$ & $1.25 \pm 0.10^{\mathrm{a}}$ & $1.37 \pm 0.20^{\mathrm{a}}$ & $1.15 \pm 0.12^{\mathrm{a}, \mathrm{b}, \mathrm{c}, \mathrm{d}}$ & 15 \\
\hline & Phosphorous acid (1B) & $1.27 \pm 0.09^{\mathrm{a}, \mathrm{b}}$ & $1.23 \pm 0.11^{\mathrm{a}, \mathrm{b}}$ & $1.22 \pm 0.06^{\mathrm{a}, \mathrm{b}}$ & $1.32 \pm 0.08^{\mathrm{a}}$ & 10 \\
\hline & Metaphosphoric acid (1C) & $1.13 \pm 0.07^{\mathrm{a}, \mathrm{b}}$ & $1.16 \pm 0.11^{\mathrm{a}, \mathrm{b}}$ & $1.12 \pm 0.11^{\mathrm{b}, \mathrm{c}}$ & $1.17 \pm 0.13^{\mathrm{a}, \mathrm{b}, \mathrm{c}, \mathrm{d}}$ & -3 \\
\hline & $\begin{array}{l}\text { Methylphosphonic acid } \\
\text { (1D) }\end{array}$ & $1.22 \pm 0.16^{\mathrm{a}, \mathrm{b}}$ & $1.20 \pm 0.06^{\mathrm{a}, \mathrm{b}}$ & $1.20 \pm 0.10^{\mathrm{a}, \mathrm{b}}$ & $1.12 \pm 0.16^{\mathrm{b}, \mathrm{c}, \mathrm{d}}$ & 2 \\
\hline & $\begin{array}{l}\text { Octadecyl phosphonic acid } \\
\text { (1E) }\end{array}$ & $0.85 \pm 0.09^{c}$ & & & & -29 \\
\hline & $\begin{array}{l}\text { Bis(2-ethylhexyl) } \\
\text { phosphate }(2 \mathrm{~A})\end{array}$ & $1.24 \pm 0.15^{\mathrm{a}, \mathrm{b}}$ & $1.15 \pm 0.13^{\mathrm{a}, \mathrm{b}}$ & $1.05 \pm 0.15^{\mathrm{b}, \mathrm{c}}$ & $1.10 \pm 0.11^{\mathrm{b}, \mathrm{c}, \mathrm{d}}$ & 1 \\
\hline & $\begin{array}{l}\text { Sodium monododecyl } \\
\text { phosphate (2B) }\end{array}$ & $1.07 \pm 0.08^{b}$ & $0.99 \pm 0.08^{c}$ & $1.00 \pm 0.09^{\mathrm{c}}$ & $0.81 \pm 0.09^{\mathrm{e}}$ & -11 \\
\hline & Diethyl phosphite (2C) & $1.28 \pm 0.18^{\mathrm{a}}$ & $1.17 \pm 0.09^{\mathrm{a}, \mathrm{b}}$ & $1.22 \pm .010^{\mathrm{a}, \mathrm{b}}$ & $1.08 \pm 0.15^{\mathrm{c}, \mathrm{d}}$ & 7 \\
\hline & $\begin{array}{l}\text { Sodium trimetaphosphate } \\
\text { (3A) }\end{array}$ & $1.25 \pm 0.25^{\mathrm{a}, \mathrm{b}}$ & $1.17 \pm 0.14^{\mathrm{a}, \mathrm{b}}$ & $1.12 \pm 0.20^{\mathrm{b}, \mathrm{c}}$ & $1.23 \pm 0.12^{\mathrm{a}, \mathrm{b}, \mathrm{c}}$ & 4 \\
\hline & $\begin{array}{l}\text { Tetrapotassium } \\
\text { pyrophosphate (3B) }\end{array}$ & $1.21 \pm 0.09^{\mathrm{a}, \mathrm{b}}$ & $1.11 \pm 0.12^{\mathrm{a}, \mathrm{b}, \mathrm{c}}$ & $1.24 \pm 0.17^{\mathrm{a}, \mathrm{b}}$ & $1.27 \pm 0.13^{\mathrm{a}, \mathrm{b}}$ & 6 \\
\hline & Polyphosphoric acid (3C) & $1.18 \pm 0.09^{\mathrm{a}, \mathrm{b}}$ & $1.10 \pm 0.06^{\mathrm{b}, \mathrm{c}}$ & $1.08 \pm 0.17^{\mathrm{b}, \mathrm{c}}$ & $1.0 \pm 0.12^{\mathrm{d}}$ & -2 \\
\hline & Phytic acid (3D) & $1.19 \pm 0.11^{\mathrm{a}, \mathrm{b}}$ & & $1.14 \pm 0.10^{\mathrm{b}, \mathrm{c}}$ & & -1 \\
\hline
\end{tabular}

* Tests conducted on bonded maple wood strips $12.7 \mathrm{~mm}$ x $88.9 \mathrm{~mm}$ with a glued $12.7 \mathrm{~mm}$ x $25.4 \mathrm{~mm}$ overlap between the two strips. Each result is shown as mean \pm standard deviation.

${ }^{* *}$ Data for a set of protein/additive combinations at a specific additive concentration were subjected to analysis of variance; the same superscript letters in a semi-column indicate that the values are not significantly different at $\mathrm{p}=0.05$. 
Table 4. Tensile strength (TS) and elongation-at-break (EAB) data for cottonseed protein (CSP) and soy protein (SP) with selected additives after hot water treatments ${ }^{*}$

\begin{tabular}{|c|c|c|c|c|c|c|}
\hline \multirow[t]{2}{*}{ Protein } & \multirow[t]{2}{*}{ Additive (code) } & \multicolumn{2}{|c|}{$0.6 \mathrm{~mm}$ maple veneer } & \multicolumn{3}{|c|}{$1.59 \mathrm{~mm}$ maple veneer } \\
\hline & & $\mathrm{TS}(\mathrm{MPa})^{* *}$ & $\begin{array}{l}\text { \# wood } \\
\text { breaks }^{* * *}\end{array}$ & TS $(\mathrm{MPa})^{* *}$ & $\begin{array}{l}\% \text { rel to } \\
\text { control }\end{array}$ & $\begin{array}{l}\text { \# wood } \\
\text { breaks }\end{array}$ \\
\hline CSP & None (0) & $3.17 \pm 0.29^{\mathrm{a}}$ & $2 / 10$ & $2.86 \pm 0.72^{c}$ & 0 & $0 / 10$ \\
\hline CSP & $\begin{array}{l}\text { Phosphoric Acid (1A), } \\
\text { 54mM }\end{array}$ & $3.30 \pm 0.19^{\mathrm{a}}$ & $4 / 10$ & $3.99 \pm 0.41^{\mathrm{a}}$ & 40 & $0 / 10$ \\
\hline CSP & $\begin{array}{l}\text { Phosphorous Acid (1B), } 54 \\
\text { Mm }\end{array}$ & $3.44 \pm 0.24^{\mathrm{a}}$ & $6 / 10$ & $3.96 \pm 0.61^{\mathrm{a}}$ & 38 & $1 / 10$ \\
\hline CSP & $\begin{array}{l}\text { Metaphosphoric Acid (1c), } \\
\text { 89mM }\end{array}$ & $3.35 \pm 0.24^{\mathrm{a}}$ & $6 / 10$ & $4.17 \pm 0.78^{\mathrm{a}}$ & 46 & $0 / 10$ \\
\hline CSP & $\begin{array}{l}\text { Methylphosphonic Acid } \\
\text { (1D), 54Mm }\end{array}$ & $3.41 \pm 0.21^{\mathrm{a}}$ & $6 / 10$ & $3.93 \pm 0.53^{\mathrm{a}}$ & 37 & $0 / 10$ \\
\hline CSP & $\begin{array}{l}\text { Bis(2-ethylhexyl) phosphate } \\
\text { (2A), 27mM }\end{array}$ & $3.34 \pm 0.31^{\mathrm{a}}$ & $3 / 10$ & $3.14 \pm 0.24^{\mathrm{b}, \mathrm{c}}$ & 10 & $0 / 10$ \\
\hline CSP & $\begin{array}{l}\text { Sodium trimetaphosphate } \\
\text { (3A), } 27 \mathrm{mM}\end{array}$ & $3.34 \pm 0.25^{\mathrm{a}}$ & $0 / 10$ & $3.25 \pm 0.32^{\mathrm{b}, \mathrm{c}}$ & 14 & $0 / 10$ \\
\hline CSP & $\begin{array}{l}\text { Tetrapotassium } \\
\text { pyrophosphate (3B), } 27 \mathrm{mM}\end{array}$ & $3.35 \pm 0.23^{\mathrm{a}}$ & $2 / 10$ & $3.54 \pm 0.44^{\mathrm{a}, \mathrm{b}, \mathrm{c}}$ & 24 & $1 / 10$ \\
\hline CSP & $\begin{array}{l}\text { Polyphosphoric Acid (3C), } \\
27 \mathrm{mM}\end{array}$ & $3.38 \pm 0.15^{\mathrm{a}}$ & $4 / 10$ & $3.71 \pm 0.44^{\mathrm{a}, \mathrm{b}}$ & 30 & $0 / 10$ \\
\hline SP & None (0) & $1.06 \pm 0.40^{\mathrm{a}}$ & $0 / 10$ & fell apart & & \\
\hline SP & $\begin{array}{l}\text { Phosphoric Acid (1A), } \\
27 \mathrm{mM}\end{array}$ & $1.00 \pm 0.31^{\mathrm{a}}$ & $0 / 10$ & fell apart & & \\
\hline SP & $\begin{array}{l}\text { Sodium trimetaphosphate } \\
\text { (3A), } 27 \mathrm{mM}\end{array}$ & $0.44 \pm 0.17^{b}$ & $0 / 10$ & fell apart & & \\
\hline SP & $\begin{array}{l}\text { Tetrapotassium } \\
\text { pyrophosphate (3B), } 27 \mathrm{mM}\end{array}$ & $0.44 \pm 0.21^{\mathrm{b}}$ & $0 / 10$ & fell apart & & \\
\hline
\end{tabular}

${ }^{*}$ Tests conducted on bonded maple wood strips $25.4 \mathrm{~mm}$ x $88.9 \mathrm{~mm}$ with a glued $25.4 \mathrm{~mm}$ x $25.4 \mathrm{~mm}$ overlap between the two strips. Each result is shown as mean \pm standard deviation.

${ }^{* *}$ Data for a set of protein/additive combinations were subjected to analysis of variance; the same superscript letters indicate that the values are not significantly different at $\mathrm{p}=0.05$.

*** Number of veneer strips that fractured (out of 10 used) during testing at places other than the additive joint. In these cases the joint was stronger than the wood veneer itself. 
Figure 1. Plot of elongation-at-break versus tensile strength for cottonseed protein samples (solid circles) and soy protein samples (open circles); $\mathrm{R}^{2}=0.9899$ for the linear correlation.

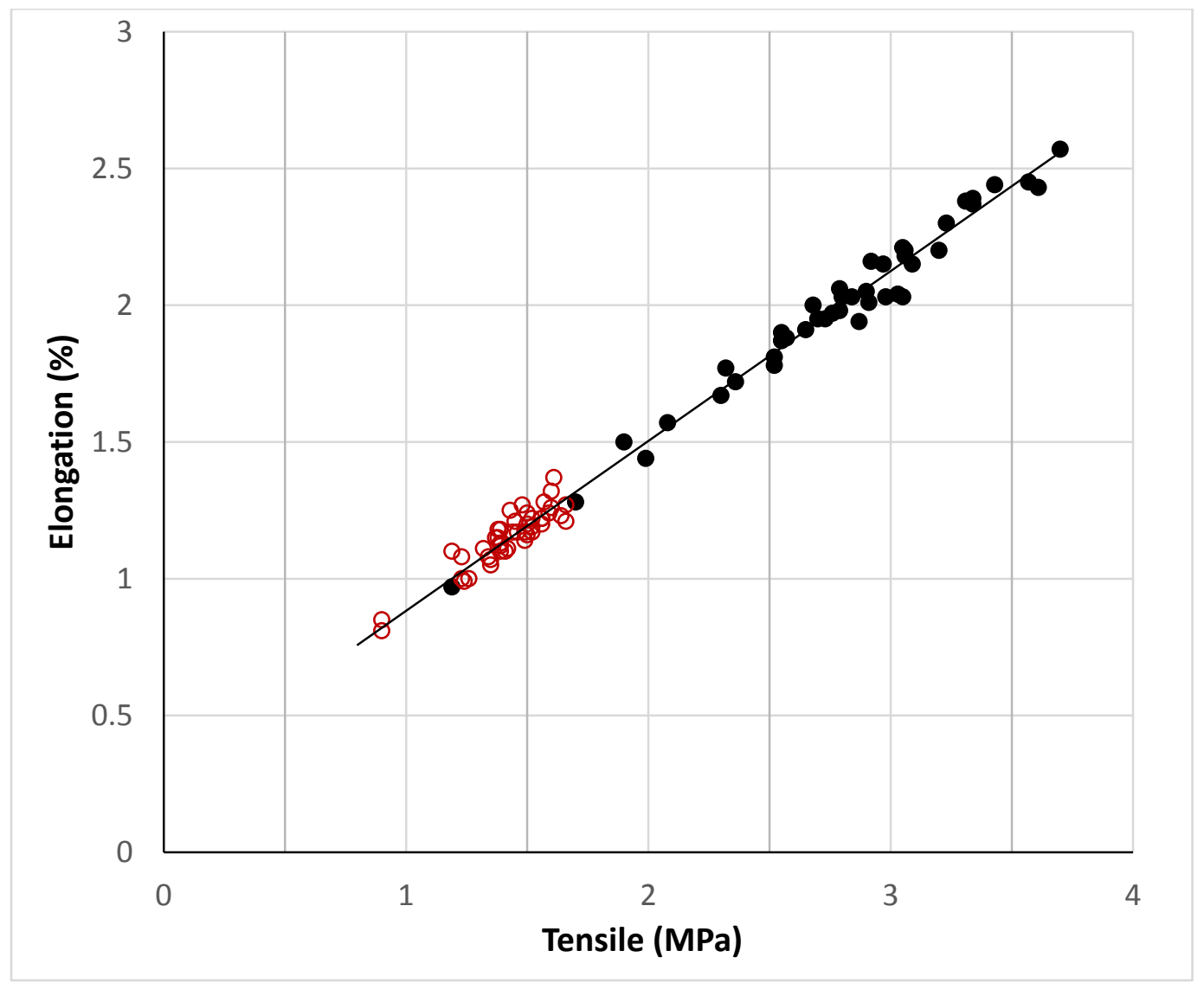


Figure 2. FT-IR spectra of (a) cottonseed protein, (b) cottonseed protein/methyl phosphonic acid, (c) cottonseed protein/phosphorous acid, and (d) cottonseed protein/phosphoric acid, all adjusted to $\mathrm{pH}$ 4.8. Spectra taken on solid samples after heated at $100^{\circ} \mathrm{C}$ for 20 minutes in a hot press.

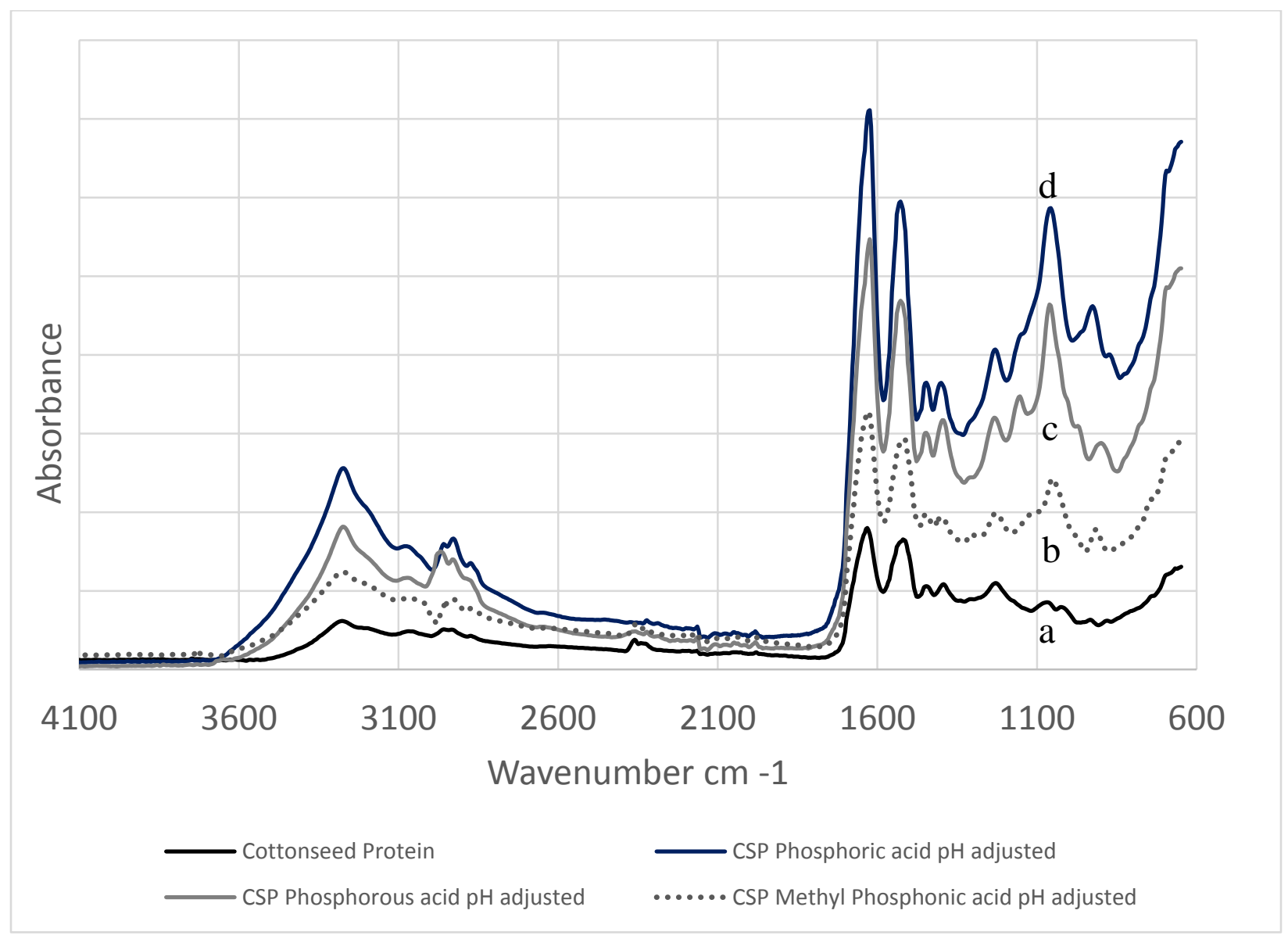


Figure 3. FT-IR spectra of a) heated solid cottonseed protein-phosphoric acid sample after spectral subtraction with pure cottonseed protein, b) phosphoric acid only, adjusted to $\mathrm{pH} 4.8$ with $\mathrm{NaOH}$

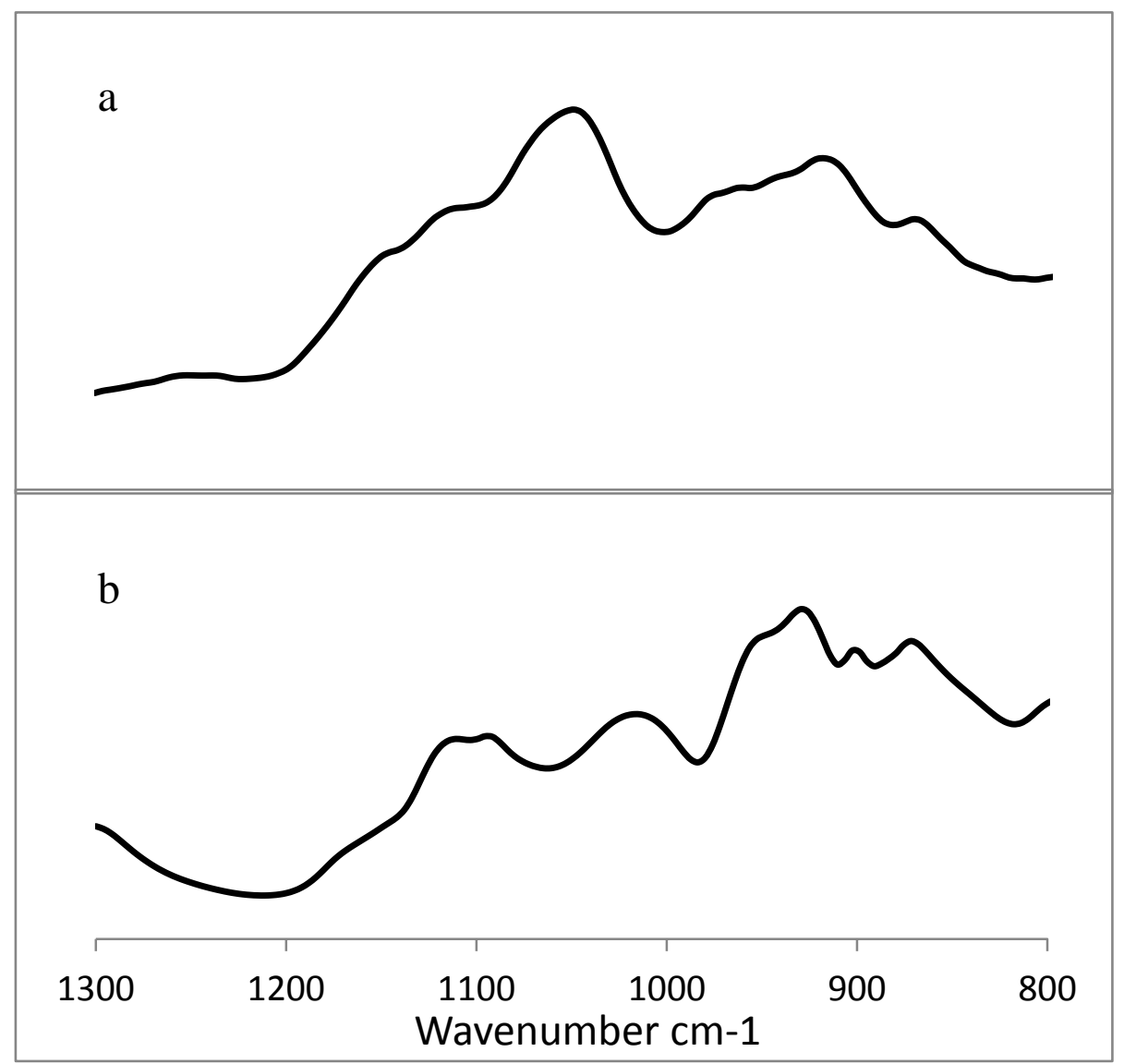

